\title{
Inclusion the Disabled Students in Higher Education in Oman
}

\author{
Ibrahim Amin Alqaryouti \\ Sultan Qaboos University, College of Education, Muscat-Oman
}

\begin{abstract}
The purpose of this study was to investigate the problems related to inclusion with special needs for Omani students in higher education. The subjects were consisted of 28 students 16 male and 12 female. Eleven students were visually handicapped and 17 students were physically handicapped. A questionnaire consisted of 59 items was used. Results indicated that there were statistically significant differences in the barriers to inclusion due to the type of disability and scored by the visually handicapped. On the other hand, there were no statistically significant differences in the obstacles of the inclusion due to the gender or the degree of the disability, but there was a statistically significant difference for the interaction of the two variables, the degree of disability and the gender.
\end{abstract}

\section{Introduction}

The inclusion of students with special needs into public schools has been a key topic of most educational systems in the world. Consequently the issue of educational inclusion is a concern for educational politics in many countries.

From the early years of the $18^{\text {th }}$ century, legislators in many countries adopted the concept of full inclusion which means creating an educational system that services equally all the students regardless of their differences. Recently, a new trend has appeared known as General Education and The Holistic School or the school that does not exclude any student. In general, many educators have advocated for the deletion of the dual educational systems (special education, general education) and for integrating them in one educational system that meets all the students' needs.

Schools were requested to carefully reconsider the education of special needs students in regular classrooms instead of placing them in more restrictive environment [6], [14], [18].

\section{Literature Review}

UNESCO [24 ] defines inclusion precisely thus: " as a process of addressing and responding to the diversity of needs of all learners through increasing participation in learning, cultures and communities, and reducing exclusion within and form education. It involves change and modifications in content, approaches, structures and strategies, with a common vision which cover all children of the appropriate age rang and a conviction that is the responsibility of the regular system to educate all children".

There are many arguments about the educational, social, and ethical issues due to the inclusion of the students with special needs in regular classrooms. Many educationalists believe that such inclusion would help disabled students to integrate better into society. In addition, the academic and social benefits enhance opportunities for the disable students and can lead to social adjustment, social sufficiency and reduce the negative effects that would appear as a result of their isolation. It may also enhance the perception of the normal student of the disabled student, and improve social and communication skills of both groups. Inclusive education can therefore be considered a pathway to attain social inclusion. From a societal perspective, inclusion education is clearly and substantially linked to the discussion around the type of society to be attained; the kind of well-being desired for all citizens; and the quality of democracy and social participation we wish to pursue. On a long-term basis, education in relation to social inclusion implies an understanding of the former as the key to citizenship and as an essential component of social policy.

On the other hand, there were many opponents for inclusion who claimed that the general education system not well prepared for such inclusion. In addition, research' results have not confirmed the effectiveness of inclusion. Added to this, the students with special needs require more intensive interference which might not be available in the general education schools. Thus, there are many considerations which should be regarded before taking such steps [4], [5], [7], [8], [17].

In order for inclusion of the students with special needs to be successful, schools and universities should accept innovation and diversity. All the participants in the education field should believe in that. These participants should also believe that the students with special needs are able to interact successfully in the learning process. Also inclusion education policies should be conceder the vast repertoire of diverse and complementary pedagogical 
strategies (formal and non formal schooling) that can respond to the needs of each student in the regular education situations. The educational staff should be supported and the educational practices should be flexible with regard to the outcomes, constructive education, assessments, and evaluation. Also strong teachers support in classroom and cooperate in developing the curriculum, and modify their teaching methods to meet the learning style of the students, and engaging in dialogue with families and communities in order to understand their expectation and needs [19], [22].

It is very essential to consider the facilities available in the school and university complexes which have to be suitable for the needs of disabled students. There should be careful attention to the design of the classrooms that has to accommodate the type of disabilities exhibited by students who are included in the classroom. Diverse severity of the disabilities represented between the disabled students in the class might need special demands from the classroom teacher. For example, those students with totally blind, deafness, physically impaired, will require a significant instructional accommodations or curriculum modifications. The classroom space, design, location, lights, elevators, and assistive tools should be considered in environmental settings [18].

There must be appropriate technology such as preferential seating, modified desks, large printed books, and wheelchairs would help disabled students to interact better with their normal peers. For that reason, it is important for the advocator of the inclusion to provide the normal students with essential information about types of disabilities and the assistive equipment which is used by their disabled peers [19], [20], [21].

The process of inclusion also requires devoting sufficient space for the storage of the equipments such as typewriters, wheelchairs, removing all the obstacles inside or outside the building to ensure safe movement also providing helping systems in the library or in the computer labs. Add to this, making normal students fully aware about their handicapped peers. Some adjustment on their dwellings which would help the disabled students in their traveling, the educational institutes should accommodate all students regardless of their physical, intellectual, emotional, social, linguistic or other conditions. Any society plan to transit towards inclusion education of the disabled students in schools or universities, should implies collective thinking and action on social justice and social inclusion; the beliefs and attitudes around the learning potential of each student; the vision and mission than sustain good teaching and learning practices; friendly environment; homes, classes, streets, recreation and public buildings; endorsing a holistic political and technical vision of curricula, media and the equipments aids encompassing processes and outcomes [1], [25].

Many studies have discussed the difficulties that face the handicapped in the educational environment. Hodges \& Keller [11] made a study aimed at recognizing the extent to which students perceive the process of inclusion the handicapped students in the university. The results indicated that there were many problems that faced visually impaired students. Such problems were in transport, and developing a social relationship with their peers.

Haugann [10] looked a study at identifying the visually handicapped students in higher educational institutions. The results indicated many different problems; for example the absence of counseling services, few numbers of Braille printed books, lack of visual readers, the difficulty of adjustment with the university life, teachers' neglect of their special needs, and the problem of taking exams and transport in were the most important.

Fuller, Healey, Bradley \& Hall [9] also studied obstacles that faced the handicapped at university. The results of the study indicated that there were many obstacles such as the fast rate of the teachers' speech during the lectures, as well as difficulty in participating in the discussion and answering the questions. Also some lecturers resented allowing disabled students to tape the lectures, and it was hard to access the educational centers. There was a lack of suitable computer programs.

Masaedeh's [15] study aimed at identifying the problems of handicapped students in Jordanian universities. The results indicated that the most obvious problems were those which were related to the services. In addition, there were many concerns about the future of disabled students, and their psychological, social, and health issues. On the other hand, the study did not show any significant differences due to the gender of the disabled grade level, type of disability.

Ibrahim [13] studied the problems of visually handicapped students in the University of Jordan. The results of the study revealed the existence of problems such as using the library, transport, difficulties in teachers' understanding about their needs. The study did not show any significant differences due to the handicapped gender, the degree of disability, level of education.

Alahmadi [3] studied the problems which were facing the physically disabled students in regular education schools. The study indicated that there were many problems related to the structure of the building and the classrooms. In addition, many handicapped students were not able to participate in different activities thus; their feelings of loneliness and isolation would increase.

Zakarya [32] pointed to a range of difficulties that were facing the handicapped students who were integrated through regular schools. Such difficulties 
were presented in the shortage of qualified staff, the negative attitudes of teachers towards them, complaints from normal peers about the behavior of the disabled students, the rejection of having any relationship with them, and the lack of suitable services provided to the handicapped in the schools.

$\mathrm{Al}$ hamad [2] also highlighted the most important problems facing physically handicapped students which include the feeling of loneliness, improper habilitation, disrespect for, their private parking, insensitivity towards them, and lack of elevators and appropriate entrances to facilitate movement.

Herz Allah [12] studied the difficulties and psychological effects that resulted from the restrictive environment of physically handicapped students. The results indicated difficulties resulting from their isolation, lack of environmental adjustments which would facilitate their movements, and difficulties in developing personal relations with normal people.

Noghoi [16] studied the problem which visually handicapped students faced in the Jordanian schools, in particular the educational, environmental, psychological, and social difficulties. On the other hand, the study did not show any different problems due to the intensity of the disability, gender, or the educational school level.

This study is based on the result of other researches' and modern educational studies in the field of educational inclusion of handicapped students in the regular educational environment. In addition, there were many obstacles that were faced by the handicapped students such as learning difficulties, unsuitable curriculum and teaching methods, and the lack of aid-equipments. Beside this, there were psychological and social problems that students faced through the educational inclusion programs. Such problems included their relationship with their peers and teachers, inability to accept each other, low self-esteem and confidence, and feelings of isolation and loneliness. In addition to the environmental obstacles, there was also a lack of facilities which negatively affected academic performance, social and psychological adjustment. This would turn the concept of inclusion into a nightmare to fulfill. This would aware us to the importance of reconsidering the idea of inclusion of those handicapped students at this university and to face such obstacles to ensure the idea of the least restrictive environment.

Accordingly, this study aimed at answering the following question:

- Are there any differences in the obstacles that facing students with special needs according to the type of their disability which are revealed by the dimensions of used instruments?

- Are there any differences in the obstacles of the inclusion of the students with special needs due to the following variables: gender, degree of disability, and the interaction between them according to the used instrument?

\section{Purpose of the study}

This study aimed at identifying the obstacles to the inclusion of the handicapped students in Sultan Qaboos University (SQU). In addition to highlight the obstacles they face in the university setting and to provide enough information to the decision makers in the university so they well are able to recognize such obstacles and consider them carefully while planning for inclusion in the university.

\section{Definition of Terms}

- Blind: the person who has lost his or her sight completely and can only perceive the light.

- Partially sighted: the person who cannot perform different work without the assistance of visual aids tools.

- $\quad$ Physically handicapped: the person who has a defect or disorders which prevents hem or her to use his body normally in different activities.

- Inclusion: reconstruction of the educational process including its educational services, curriculum, and the rehabilitation of the staff's beliefs and roles in the educational field in order to meet the needs of special needs students.

\section{Analysis of Findings}

\subsection{Sample}

The sample of the study consisted of 28 physically and visually handicapped students according to the information from the Dean of Students' Affairs in SQU during the year 2008/2009. There were nearly 11 visually handicapped students, 17 physically handicapped students, 9 students with mild disability, and 19 students with moderate disabilities.

There were 16 male students and 12 female students. Twenty of these students were in humanitarian colleges and 8 in scientific colleges.

\subsection{Instrument}

The researcher used a questionnaire designed by Noghoi [16]. To meet the purpose of this study, the researcher deleted and added some items to the instrument. The initial version consisted of 67 items. 
The researcher presented his instrument to a panel of nine judges who were specialists in psychology and special education in the faculty of education in SQU. After reviewing the questionnaire, the researcher completed the requested changes, the final print consisted of (59) items, distributed among the following four domains:

- The Educational Domain (EdD): this domain consisted of (16) items. Examples of these items are: "part of the curriculum which I study does not meet the nature of my disability".

"Some teachers are annoyed when I use my special assistive tool inside the classroom".

- The Social Domain (SD): This domain consisted of (14) items. Examples of these items are: "my classmates hesitate before asking me to join them for a walk".

"I feel embarrassed about the repeated questions about the nature of my disability".

- The Psychological Domain (PD): This domain consisted of (13) items. Examples of these items are: "I feel angry about others' sarcasm while I am moving in the university".

"I feel annoyed about some of teachers' complains about my presence in their classes."

- The Environmental Domain (ED): This domain consisted of (16) item. Examples of these items are: "There are no special parks for the handicapped near the faculty's building".

"Some barriers and obstacles into university endanger my life".

The researcher estimated the reliability of the instrument by using Cronbachs Alpha Coefficient which was for the first domain (0.93), for the second domain (0.86), for the third domain was (0.86), for the fourth domain (0.77), and for the whole instrument it was (0.93).

\subsection{Procedures}

With the help of some female students from the early childhood education department, the researcher distributed the questionnaire to the members of the sample. The Data was collected during the second semester of (2009), and then it was estimated by using the statistical program (SPSS). Analyzing the results was according to the variables of the study.

\section{Results}

To answer the first question, the researcher estimated the mean scores and the standard deviation of the sample about the domains of the instrument which are explained in table (1).

Table 1. The mean scores and the standard deviations of the sample responses at the domains of the instrument according to the student's category

\begin{tabular}{|l|l|l|}
\hline $\begin{array}{l}\text { Type of } \\
\text { Disability }\end{array}$ & Mean & S.D. \\
\hline Blind & 16.700 & 5.078 \\
Physically & 6.500 & 1.653 \\
\hline Blind & 37.400 & 11.037 \\
Physically & 21.944 & 7.596 \\
\hline Blind & 28.500 & 10.373 \\
Physically & 21.222 & 9.078 \\
\hline Blind & 45.100 & 10.126 \\
Physically & 23.055 & 8.673 \\
\hline
\end{tabular}

From the above table, it is evident that there were differences in the mean scores between the visually and physically handicapped students in the different domains of the instrument. And to be sure about the indications of these differences, the researcher estimated the value of (f) for One Way ANOVA explained in Table 2.

Table 2. The One Way ANOVA Analysis of the differences in the degree of the disabilities in the domains of the instrument with each different student's category

\begin{tabular}{|c|c|c|c|c|c|}
\hline $\begin{array}{c}\text { Source of } \\
\text { differences }\end{array}$ & $\begin{array}{c}\text { Sum } \\
\text { squares }\end{array}$ & $\begin{array}{c}\text { Degree } \\
\text { of } \\
\text { Freedom }\end{array}$ & $\begin{array}{c}\text { Mean of } \\
\text { Sum } \\
\text { squares }\end{array}$ & (F) Value & Alpha \\
\hline EdD & 544.11 & 1 & 544.11 & 50.779 & 0.00 \\
\hline SD & 1535.62 & 1 & & 19.1221 & 0.00 \\
\hline PD & 340.496 & 1 & & 3.736 & 0.064 \\
\hline ED & 1654.87 & 1 & & 19.541 & 0.00 \\
\hline
\end{tabular}

According to Table (2), it was clear that there was a statistically significant difference among the domains of the instrument. The first was the educational domain, the second was the social domain, and the fourth was the environmental domain and scored by the visually handicapped students.

To answer the second question, the researcher estimated the mean scores and the standard deviation of the sample seen in table 3 . 
Table 3. The mean scores and standard deviation of the sample responses at the instruments domains according to the gender and the degree of disability

\begin{tabular}{|c|c|c|c|c|}
\hline Domain & Gender & Degree & Mean & S.D \\
\hline EdD & Male & Mild & 9.00 & 2.708 \\
& & Moderate & 10.50 & 4.582 \\
& \multirow{2}{*}{ female } & Mild & 11.60 & 7.956 \\
& & Moderate & 11.71 & 6.993 \\
\hline SD & Male & Mild & 38.75 & 11.221 \\
& & Moderate & 24.75 & 9.854 \\
& & Mild & 21.40 & 13.794 \\
& female & Moderate & 30.00 & 7.6376 \\
\hline PD & Male & Mild & 30.25 & 12.365 \\
& & Moderate & 24.08 & 9.307 \\
& & Mild & 17.80 & 7.823 \\
& \multirow{4}{*}{ female } & Moderate & 24.00 & 10.84 \\
\hline \multirow{2}{*}{ ED } & Male & Mild & 29.50 & 6.137 \\
& & Moderate & 36.83 & 12.967 \\
& & Mild & 36.40 & 16.1647 \\
& female & Moderate & 33.14 & 10.447 \\
\hline
\end{tabular}

And to estimate the value of Alpha, the researcher did The Analysis of Covariance, explained in Table 4.

Table 4. The Analysis of Covariance to explain the differences in the inclusion of the students according to the gender and the degree of disability variables and the interaction between them

\begin{tabular}{|c|c|c|c|c|c|}
\hline & $\begin{array}{c}\text { Source of } \\
\text { difference }\end{array}$ & $\begin{array}{c}\text { Sum } \\
\text { squares }\end{array}$ & DF & $\begin{array}{c}\text { Mean } \\
\text { Sum } \\
\text { squares }\end{array}$ & $\begin{array}{c}\text { F) } \\
\text { Value }\end{array}$ \\
\hline Gender & EdD & 21.516 & 1 & 21.516 & 0.646 \\
$(1)$ & SD & 216.522 & 1 & 216.522 & 1.865 \\
& PD & 232.308 & 1 & 232.308 & 2.360 \\
& ED & 15.234 & 1 & 15.234 & 0.100 \\
\hline Degree & EdD & 3.854 & 1 & 3.854 & 0.116 \\
of & SD & 43.124 & 1 & 43.124 & 0.371 \\
Disability & PD & 0.002 & 1 & 0.002 & 0.000 \\
$(2)$ & ED & 24.572 & 1 & 24.572 & 0.161 \\
\hline$(2 \times 1)$ & EdD & 2.840 & 1 & 2.840 & 0.085 \\
& SD & 755.349 & 1 & 755.349 & 6.506 \\
& PD & 226.171 & 1 & 226.171 & 2.298 \\
& ED & 165.868 & 1 & 165.868 & 1.087 \\
\hline
\end{tabular}

According to Table (4), there was no statistically significant difference due to the gender and degree of disability variables in all the instrument domains. On the other hand, there was a significant difference in the interaction between the gender and the degree of disability in the social domain only.

Figure (1) explained the interaction between the gender and the degree of disability in the social domain.

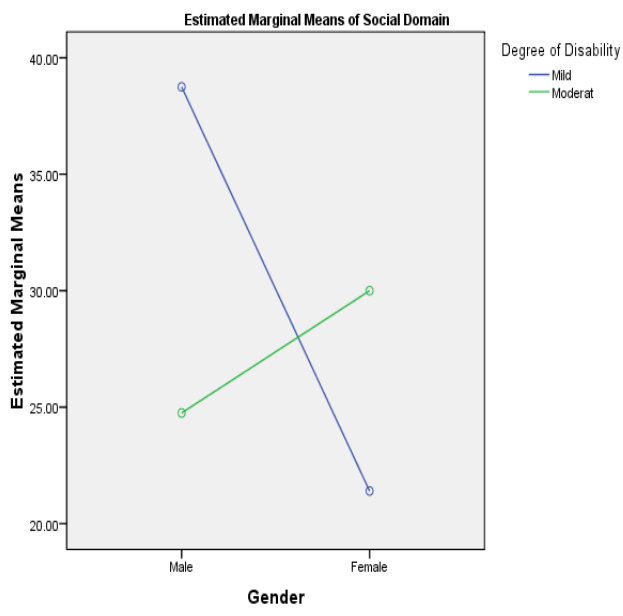

Figure 1. The interaction between the gender and the degree of disability in the social domain

\section{Discussion}

This study aimed at identifying the barriers to inclusion of the students with special needs in SQU. The results of the study showed that there were statistically significant differences in these obstacles due to the type of disability among the visually handicapped students who indicated obvious problems within the first domain. They suffered from problems of following the curriculum, test performance, and writing a research paper. This might have resulted from the type of the disability from which they suffer and from the other side, the materials they used through their writing and reading. The visually handicapped student used the Braille method in reading and writing which is very slow and needed twice the amount of time compared to the time needed in regular reading and writing.

In addition, it was difficult for regular teachers to read in the Braille method. This made the situation more complicated especially when the handicapped students needed some help from their classmates during the exam period. This might be difficult because their normal peers would be also involved in their own revision for the exams.

The results also indicated that the visually handicapped student had problems in the social domain compared to the physically handicapped students. This might be a result of their inability to interact with other people, of being neglected, lack of activities that helped the visually handicapped students to interact with normal peers inside the university which increase the distance in between them.

The study indicated that there were some problems for the visually handicapped students in the environmental domain. These problems might occur because the visually handicapped students might not reach the lectures, restaurants or other places which 
were eases to reach for the physically handicapped students.

The environmental conditions were often a source of danger for the visually handicapped students because they had not practiced reaching these places and they did not receive any help from other normal peers.

This result agreed with what Hodge \& Keller [11] and Hougann [10] discovered in their studies. In addition, the result of this study agreed with the results of Al- hamad [2], Ibrahim [13], and Noghoi [16]. The results of the previous researches identified the educational, social and environmental problems that the visually handicapped students would encounter at the university. Such results made the supervisors and the other people responsible aware about the places that might be needed to be trained the visually handicapped students. Some of the suggestions that SQU might consider are discussed in the following paragraph:

The assistive tools which would help the visually handicapped students in getting the required information from the libraries must be made available. Providing the teachers who might teach those handicapped students with enough information about these students, the assistive tools they need and the alternative assessment that teachers need in their evaluation and making the handicapped students more familiar with buildings in their universities which would facilitate their movements from one building to another.

Add to this, there must be well qualified staff that recognizes students' needs, availability of recorded books, making the normal students more aware of the difficulties that their visually handicapped students encounter, and choosing suitable activities that would help the visually handicapped students to interact effectively.

Concerning the gender and the degree of disability variables, the result did not show any statistical difference between the male or female handicapped nor between the mild or moderate disability. This result agreed with what was found in the study made by Ibrahim [13], Noghoi [16], and Masaedeh [15]. According to the result of this study, it was found that obstacles to inclusion in the university would happen regardless of the gender or the degree of the disability of the handicapped. The researcher pointed at those variables as a part of the limitation of the study. This happened because the few number of cases in cells, which did not help the researcher to analyze the gender variable from each type of the examined disability. Add to this, there were not any sever cases in the sample of the study which limited the study to only the mild and moderate disabilities.

The study also indicated that there were significant differences from the interaction between the gender and the degree of disability the social domain. Figure 1 indicated that male students with mild disability suffered from social problems more than female students with mild disability. This might be due to the nature of the social activities, the interactive social level between the members of the society whether male or female. In addition, the type of the social activities performed by the handicapped would decide if the he would do or not. For example, traveling and social occasions might be obstacles for handicapped males only since the handicapped females would not participate in such occasions according to the customs of the Omani society.

The figure also indicated that handicapped females who had moderate disabilities faced more social problems than male counterparts. Generally, the difficulties the handicapped meet increased by the degree of disability, and the difficulties are connected with the nature of the disability itself, if the disability was visible and noticeable. Such situations would make the handicapped more embarrassed.

Added to this, when the female disabled students used the assistive tools, they would become embarrassed. This caused more social distance for them and forces them to keep themselves isolated.

In order to increase the social interaction between the normal students and the handicapped students, the researcher suggested that the university should present a course about the students with special needs as an obligatory course. Thus, the students would become more familiar with the abilities of their handicapped peers, develop positive attitudes towards them, modify some misconceptions about handicaps, and contribute to the future education of the society about the handicaps in order to create a civilized environment which accept the differences between each other and respect them.

\section{Future Work}

The researcher also recommended other researchers to study the counseling and psychological needs of the handicapped students, the relationship between their self esteem and academic achievement, and their psychological stability.

\section{References}

[1]O.Abosi \& T. koay, “Attaining development goals of children with disabilities: Implications for Inclusive education”, International Journal of Special

Education, 2008, 23, 3, 1-10.

[2]N.Al hamad, The counseling needs for physical handicap and their relation to some variables in Irbed district. Unpublished thesis. Yanmouk University, Amman: Jordan, 2001.

[3]M.Alahmadi, “The Problems of integrated physical handicapped students in Almadina Almonawarh 
Schoo", The Arabia Journals for Special Education, 2007, 10, 13-92.

[4]N.Burstein, K. Sears, A.Wilcoxen, B. Cabllo, \& M. Spagna. "Moving toward inclusion practices". Remedial and Special Education, 2004, 25, 104 -110.

[5]J.Begeny\& B.Martens, Exclusionary education in Italy. Remedial and Special Education, 2007,281, 2, 80 -94.

[6]R.Culatta, \& J. Tompkins, Fundamentals of special education. Prentice - Hall, IAC,1999.

[7]L.Cushing, E.Carter, N.Clark, T.Wallis, \& C. Kennedy.” Evaluating inclusive educational practices for students with severe disabilities using the program quality measurement tool”. The Journal of Special Education, 2009, 42, 4, 195-208.

[8]D. Fuchs, \& L. Fuchs, "Inclusive school movement and the radicalization of special education reform". Exceptional Children, 1994, 60, 299-309.

[9]M. Fuller, M. Healey, A. Bradley, \& Y. Hall , “ Barriers to learning , a systematic study of the experience of disabled students in one university". Studies in Higher Education, 2004, 29, 3, 303-318.

[10]E. Hougann, "Visually impaired students in higher education in Norway". Journal of visual Impairment and Blindness, 1987, 4, 92, 235 -250.

[11]J. Hogde, \& J. Keller, "Visually impaired students perception of their social integration in college". Journal of Visual Impairment and Blindness, 1999, 3 , 2, $149-162$

[12]M. Herz Allah, The parries and psychological effects faced by the disabled persons. Paper Presented at the scientific symposium for disabled. Amman: Jordan, 1995.

[13]M.Ibrahim, The problems of visually impaired students in Jordanian university. Un published thesis Jordan university, Amman: Jordan, 2001.

[14]J.Jenkins, C. Plous, \& M. Jewell, M. “Special Education and the regular education Initiative: Basic assumption”. Exceptional Children, 1990, 56, 479491.

[15]A.Masaedeh, The Problems of the handicapped student in Jordanian University, Unpublished thesis. Yarmouk University, Irbed: Jordan, 1995.

[16]H. Noghoi, The problems of visually impaired students integrated in Jordanian school and their relation to variables of impairment severity, gender and educational stage, unpublished thesis. Amman Arab University from higher studies, Amman: Jordan, 2007.

[17]G.Peltier,” The effect of inclusion on non-disabled children: A review of the research". Contemporary Education, 1997, 68, 234-238.
[18]M.Schmidt, \& B. Cagran, "self-concept of students in inclusive settings". International Journal of Special Education, 2008, 23, 1, 8 -17.

[19]C. Schaffner, \& B. Buswel, Ten critical elements to create inclusive and effective school communities. In S. Stainback \& W.Stainback. (Eds) Inclusion A guide for teacher, pp.49- 65 (Baltimor, MD,Paul Brookes),1996.

[20]J. Vanderfaellie, F.Fever, \& K. Lombeats. "First- year university student's of educational sciences on inclusion education: attitudes and convictions in Flanders”. European Journal of Teacher Education, 2003, 26, 2, $265-277$.

[21]D.Wadsworthe, \& D. Dnight, "Preparing the inclusion classroom for students with special physical and health needs". Intervention in School and Clinic, 1999, 34, 3, 1-8.

[22]J. Zolizan, "Perception of inclusion education Practices: the Malaysian Perspective”. Education Review, 2000, 52, 2, 187 -196.

[23]Z. Zakarya, "zero rejected schools”. New education Journal, 1995, 1, 65 -87.

[24] UNESCO. Guidelines for inclusion: ensuring access to education for all, 2005, Paris: UNESCO.

[25] M, Nind, "Inclusive education: discourse and action". British educational research journal, 2005, 31, 2,269275. 